\title{
Teachers' Use of Assessment Data in Secondary Schools in Kenya: Opportunities and Threats
}

\author{
George Okoth Jawuor \\ Ph.D. Candidate, Department of Education Planning and Policy Studies \\ Kenyatta University, P.O. Box 43844 \\ Nairobi, Kenya \\ E-mail: ggokoth@gmail.com \\ Accepted: March 31, 2020 \\ Published: April 20, 2020 \\ URL: https://doi.org/10.5296/gjes.v6i1.16199
}

Received: January 7, 2020

doi:10.5296/gjes.v6i1.16199

\begin{abstract}
Governments around the world are pushing educators to adopt assessment data as an objective basis for initiating changes in curriculum and instruction. Recent research findings indicate that teachers' effective and consistent use of assessment data in curriculum planning, implementation and monitoring of teaching improves the learners' overall academic achievement. This paper is a product of a desktop review of the limited cognate literature present in Kenya on the utility of assessment data for decision making in secondary schools. Although findings reveal that Kenyan teachers use assessment data among others to; identify weak learners for individual remedial programs, inform parents of their children's academic progress and for career selection, the instructors' intensive use of data in classrooms to drive meaningful positive change faces pervasive bottlenecks. Teachers need to exploit the available opportunities created by the government, such as in-service training on information communications technology, to enhance the use of assessment data to promote learning.
\end{abstract}

Keywords: assessment data, data-based decision making, decision making, education data, data use

\section{Introduction}

The secondary education system in Kenya is inundated with a high number of assessments. The Naomi Wangai Report on Students Discipline and Unrest in Secondary Schools in 2001 acknowledges the high frequency of administration of school examinations and indicates that the number of tests learners do as part of assessment are excessive and could be the cause of incessant school unrests (Republic of Kenya, 2001). The report further recommends a significant reduction in the number of tests in schools to stem the periodic wave of student unrests in the country. Boit, Njoki, and Changach (2012) also point out that there are too many types of assessments in Kenya which only perpetuate item teaching in order to improve learner pass rates as opposed to holistic curriculum implementation. According to Buhere (2010), there is "too much assessment of learners" (p. 7) in schools, which reduces the quality of instructional contact time between teachers and learners. Henry, Nyaga, and Oundo (2014) 
regrets that the quantity of tests in schools is a heavy load the learners have to contend with. They say, "the schools overburden the learners with frequent assessments" (Henry, Nyaga, \& Oundo, 2014, p. 59).

These lamentations demonstrate one major issue in schools in the country: that the nation's basic education sector relentlessly produces huge amounts of assessment data. That notwithstanding, the production of these vast quantity of assessment data may not be that bad. Educators conceded that the quantity and effective use of testing results is what brings out the bold difference in performance that exists between high and low academically achieving schools (Stachowiak, 2013). In effective schools, Lezotte (2001) indicates, "pupil progress over essential objectives are measured frequently, monitored frequently and the results of those assessments are used to improve the individual student's behavior and performances as well as to improve the curriculum as a whole" (p.8), unlike in ineffective schools.

\subsection{School Calendar and Curriculum}

Indeed, the country's education system is the factory that churns out plenty of assessment data every school session in a year. In every school term, all the subjects produce significant amount of test score data. How? The school calendar for the basic education, in which the secondary education falls, runs from January to November, divided into three terms. A term consists of three consecutive learning months. The first term begins from the month of January and ends in March. The second term begins from May and runs through to July while the last academic term in a school year covers the months of September, October, and November. A one-month recess separates the three terms. The months of April, August and December are the official school recess periods, commonly referred to as school holidays in Kenya.

There are four categories of schools in Kenya: sub-county, county, extra county and national. Depending on the category of the school, the forms one and two students register for a minimum of 11 examinable subjects while forms 3 and 4 learners register for a minimum of 7 and a maximum of 8 subjects. Table 1 gives the five main groups of the curriculum subjects offered in Kenyan schools from which students pick their subjects.

Table 1. The curriculum in secondary schools in Kenya

\begin{tabular}{ccl}
\hline Group & Name & \multicolumn{1}{c}{ Subjects } \\
\hline 1 & Service subjects & English, Kiswahili, Mathematics \\
2 & Sciences & Biology, Physics, Chemistry \\
3 & Humanities & History, Geography, Religious Studies \\
4 & Technical and Creative Arts & Building and Construction, Power Mechanics, \\
& & Electricity, Drawing and Design, Art and Design, \\
& & Agriculture, Metal Work, Woodwork, Aviation \\
& & Technology \\
5 & Business and Foreign Languages & French, German, Business Studies \\
\hline
\end{tabular}

Source: Republic of Kenya, 2008.

The learners choose subjects according to the following criteria: all group 1 subjects are 
compulsory (core) and are mandatory for all students pursuing the secondary education curriculum. The remaining groups 2,3,4 and 5 are elective subjects. A student has the liberty of choosing only two subjects from group 2 and only one from each of the remaining groups 3, 4, and 5 (Republic of Kenya, 2008).

\subsection{Types of Assessment in Secondary Schools in Kenya}

In terms of evaluation, the Ministry of Education policy on assessment of learners stipulates two forms of assessment: formative and summative assessments (Republic of Kenya, 2011). Formative assessments are interactive frequent assessments of instruction administered by teachers to identify the students' learning needs (Earl, 2012). The forms of formative periodic learner assessments are highly encouraged to gauge the extent to which both teachers and learners are achieving learning objectives. The government considers formative assessments as an objective way of evaluating the quality of achievement of curriculum objectives hence the call for continuous administration. The state's policy on assessment urges teachers to ensure that education quality in public schools is maintained by "carrying out continuous assessments and using them to guide learners towards better performance" (Republic of Kenya, 2011, p. 65). The formative assessments take the form of quizzes, projects and continuous assessment tests (Mackatiani, Joseph, \& Komo, 2017).

The government policy on the exact number of continuous assessments tests allowable per subject in a term for every student is not clear. The minimum number of continuous assessments tests (CATs) teachers can administer to learners is not defined in the perused policy documents. CATs are structured short term tests teachers set, administer, mark, grade and use the feedback to ascertain whether learners have mastered certain curriculum skills and competencies (Mmasi \& Thinguri, 2017). This lacuna, places the responsibility of determining the number of assessments for the students in every school on the shoulders of teachers and principals. It is the prerogative of the teacher to determine the number of tests for his/her learners. However, for the sake of uniformity in administration, most schools have CAT policies that determine the quantity and quality of CATs. Depending on the school's financial position, the purpose of assessment, grade level, the term, and internal assessment policy, the number of closed book continuous assessments tests may vary from two in sub-county schools to four in national schools in a term.

In order to meet the overall goal of academic improvement, teachers in most secondary schools administer three closed book continuous assessments each term. The three continuous assessment tests mean that in each term, a student sits three different examinations for each enrolled subject, one examination per subject every month. Assuming that the subject is Mathematics, a student in say form one class is required to write three different Mathematics examinations (or continuous assessment tests) in term one, another set of three in the second term, and the same number applies in the third final term of the academic year. By the end of each school calendar year, the student would have been examined nine different times using nine testing instruments in Mathematics alone, producing plenty of Mathematics assessment data.

This mode of three-CATs in secondary school begins when learners are admitted in form one in term one every school calendar year. So, at the time of exiting the secondary school system 
after the fourth year in November, a student would have done a minimum of 36 different formative Mathematics assessments! Another 36 different English continuous assessment tests, the same with Kiswahili, Chemistry, and so on. This excludes the other classroom-based assessments such as quizzes, projects, and joint school examinations and contests. The fundamental concern that this essay seeks to answer is how teachers use the massive amount assessment data generated from tests in decision making in schools.

The summative assessment on the other hand are forms of assessment administered to learners at the end of either a learning period or a program. Burket (2016) stated that summative assessments are administered to learners at the conclusion of a defined program, unit of study, or school year to evaluate skill acquisition, student learning and academic achievement. In Kenya, summative assessments are examinations offered to form four candidates by the Kenya National Examination Council (KNEC), to mark the end of four years of secondary education. KNEC is the central body, solely in charge of developing examination policies and procedures, setting, administration, marking and grading of the national examinations in Kenya. It was established through an Act of Parliament in 1981, and later revised in 2012.

The government uses mean grades (data) of the said national examinations to among others; select form four candidates for placement in post-secondary training institutions and universities (Republic of Kenya, 2019). The minimum grade for university admission is $\mathrm{C}+$ (Nasibi, 2003). Candidates who obtain mean grades of between $\mathrm{C}+$ and A plain are eligible for university education, while the $\mathrm{C}$ and $\mathrm{C}$ - achievers get placement in training colleges. The technical and vocational institutions absorb the remaining candidates who obtain grades D+ and D in the national examinations (Republic of Kenya, 2018). Teachers in schools have also been found to use qualitative and quantitative data from summative assessments to streamline their instruction (Burket, 2016). The KNEC grading pattern ranges from A to $\mathrm{E}$ and includes A, A-, B+, B, B-, C+, C, C-, D+, D, D-, E. Table 2 shows the grading pattern and respective scores used in Kenya.

Table 2. Examinations Grading Pattern in Kenya

\begin{tabular}{lllllllllllll}
\hline Grade & A & A- & B+ & B & B- & C+ & C & C- & D+ & D & D- & E \\
Score & 12 & 11 & 10 & 9 & 8 & 7 & 6 & 5 & 4 & 3 & 2 & 1 \\
\hline
\end{tabular}

Source: Republic of Kenya, 2018.

Research indicates that learners in schools with frequent assessments have got better academic performance records in standardized assessments. Frequent assessments are essential to learning in the sense that they improve student academic achievement, especially when teachers choose to use the feedback effectively to promote instruction (Rudner \& Boston, 2003). Young and Kim (2010) rhetorically posed the question, "If teachers are not using assessment data to inform instruction related decisions, then for what purpose are assessments held in schools?" (p. 6). How then do Kenyan teachers use this massive amount of data generated from the numerous frequent tests in schools? What challenges do teachers 
face in data driven decision making? As Wayman (2005) once posed, are schools in Kenya 'data-rich' yet 'information poor'?

This paper presents the results of a desk review of literature on teachers' use of assessment data in classrooms in Kenya. The essay also deals with institutional weaknesses teachers navigate daily to upscale data use in decision making in secondary schools.

\section{Literature Review}

Research posits that data use is essential to achieving quality education. Effective use of assessment data improves student academic achievement (Black \& William, 1998; Carlson, Borman, \& Robinson, 2011; Marsh, Pane, \& Hamilton, 2006; Marston et al., 2007). Teachers who use assessment data regularly to inform the decisions they make during instruction are more successful in improving learning outcomes (Stachowiak, 2013). Generally, assessment data helps teachers in three distinct ways: diagnosis, evaluation and prediction (Perie, Marion, \& Gong, 2009). In diagnosis function, assessment data is used to identify the problematic areas of the curriculum learners have difficulties comprehending (Schildkamp, Poortman, \& Handezalts, 2016).

In evaluation, assessment data assists educators evaluate the effectiveness of their teaching-learning interventions (Perie et al., 2009). Besides, assessment data also establishes which pedagogical solutions are most successful in bringing out the desired academic improvement (Marsh et al., 2006). Concomitantly, teachers also assess the effectiveness of their instructional strategies using assessment data to view their efforts in classrooms (Breiter $\&$ Light, 2006). The third and last use of assessment data in decision making occurs when teachers are able to predict or project the learner's future possible grade attainments based on previous academic results (Perie et al., 2009). Perie et al. (2009) argue that if all factors are kept constant, teachers are able to use academic prediction models based on data to suggest future education attainment of their learners.

Hoover and Abrams (2013) examined the extent to which classroom teachers reported using summative assessment data. The study was a web based, survey monkey, investigation, administered to 500 elementary, middle and high school teachers in Virginia. Teachers reported using data to, among others, evaluate their instructional practices, make adjustments to support learning and regroup learners based on data. The use of data to support decisions was however, irregular and less often.

Oláh, Lawrence, and Riggan (2010) also examined how teachers used assessment data to inform their instructional decisions. The researchers found that teachers used the benchmark assessment data to identify weakness in the item, content and students. Secondly, teachers also validated each test item to better understand students' responses.

Militelo, Bass, Jackson, and Wang (2013) used Q-methodology to study the perceptions of teachers and principals on how they used data in schools. Although Q-methodology findings are not generalizable, it provides informative and transferrable results. The findings revealed that principals used data to evaluate the whole school and harness the best management practices that lead to the overall school improvement while teachers used the assessment data to support classroom based decisions. 
According to Education Commission on the States (2002), teachers need to undertake six different activities after collection and analysis of assessment data. Teachers should use the data in i) tracking students' academic achievements, ii) changing the attitude of teachers about the potential success of poorly performing learners, iii) guiding the teacher's professional development, iv) linking the running interventions to results, v) formulating school improvement plans, and vi) determining school resource allocations.

\section{Research Methods}

The study used a desk research review to investigate how teachers use assessment data in decision making in schools in Kenya. Desk research involves collecting data from existing published secondary data (Khombe, 2014). I reviewed journal articles, government reports, books on teachers' data use practices in Kenya. Desk research is preferred over traditional research designs since it is cost effective and involves limited use of resources (Management Study Guide, 2012. More significantly, desk research is also used to establish the state of knowledge about the matter under investigation before carrying out the actual primary data collection (Jackson, 1994). As a postgraduate student, I used desk research to review literature for chapter two of my dissertation and consequently felt the need to share the findings of the review exercise with a wider audience before embarking on the actual primary data collection exercise.

\section{Findings}

\subsection{Teachers' Use of Assessment Data in Kenya Schools}

Teachers in Kenya use assessment data in classrooms to do the following listed activities:

\subsubsection{Individualized Education Programme}

The latest online teacher performance appraisal policy requires every teacher to keep a record of learners who need extra academic support (Republic of Kenya, 2017). Teachers use the results of the existing formative assessments to identify academically weak learners for individualized education programs. The teachers ask the poorly performing students to join the individualized education and re-teaching programmes. Teachers conduct remedial programs for the weak students and in some cases teach both groups of learners. In Kenya, Wanjiru (2011) observes, "teachers conducted remedial teaching once a week and over the weekends in their schools" (p. 67). As Anderson, Leithwood and Strauss (2010), Italiano and Hine (2014) and Marsh et al. (2006) point out, teachers make selection decisions about academically struggling learners through the use of formative assessment data and also in developing the mechanisms to narrow the achievement gaps between the weak and strong groups. Teachers in the high performing districts recognize the need to provide extra tuition help to students who fail to reach the minimum proficiency standards in learning. At the same time, the same tutors administer frequent academic practices to the learners who have mastered the learning concepts to ensure retention of the learned concepts (Cawelti \& Protheroe, 2001).

\subsubsection{To Identify Learning Difficulties}

Teachers use school-based assessments to diagnose students' learning difficulties experienced in the course of instruction. Teachers use the assessment data from the standardized national 
examinations to identify the difficult concepts in the course outline learners struggle to understand (Omoso, 2012). The teachers can then search for solutions to mitigate the learning difficulties contributing to the dismal academic results in their own subjects. One of the ways through which teachers investigate solutions to address the academic challenges in schools is by benchmarking. Benchmarking is a practice where teachers and students of one school, normally, an academically struggling institution, visiting another academically outstanding school to learn and selectively borrow their best practices for academic improvement. Every year, schools with good academic reputation hosts a number of others keen on improving their performance in national examinations.

\subsubsection{School Policy Development}

Most schools develop policies during the analysis and interpretation of the results of national assessments (Mackatiani et al., 2017). It is thus common to find that schools develop strategies and actions geared towards improving the education standards after critical analysis of the nationally standardized performance data during staff meetings. In such meetings, teachers brainstorm and develop measures to either maintain academic standards or reverse the declining performance as the case may be (Omoso, 2012).

One of the significant policies ever formulated in Kenyan schools for improving academic standards is the 'early form four syllabus completion'. Schools have created extra time for the teachers to finish up the secondary school subjects' syllabus in either first term or second term as a strategy to maintain and improve the academic standards. The Ministry of Education guidelines recommend that teachers should complete the entire secondary school curriculum by October every year in preparation for the November national examinations. However, several school teachers finish their syllabuses early, by May rather than in October to give them ample revision time (Omoso, 2012).

\subsubsection{Grading of Students}

Teachers and school leaders in Kenya have regularly used both formative and summative data to grade learners in schools. Kagete (2013) reports that "the results indicate that assigning grades is the most popular use of assessment results" (p. 8). The most crucial use of assessment data is to determine the academic attainment of a learner in relation to other students (norm-referenced assessment) and also to establish the academic achievement in relation to the main criteria, that is grade A, (criterion-referenced assessment). Parents expect that after three months of academic sojourn in schools, the children should return home with a progress report indicating their level of performance in each subject relative to grade A. The teachers issue an academic progress report which is an official summary of the learner's academic achievement for the term. This performance data is useful in monitoring the academic progress of each child from time to time.

\subsubsection{Post-Secondary Career Selection}

Teachers in Kenya use assessment data to advise the learners on future possible career pathways. To be eligible for admission into a particular degree or diploma program a student must meet the minimum average grade for the seven registered subjects. In professional courses such as medicine and law, a student must also obtain a minimum prescribed academic achievement in certain compulsory subjects (Wabwoba \& Mwakondo, 2011). Assessment 
data forms a critical, objective, and dependable factor in determining a candidate's eligibility for a particular post-secondary education program.

Teacher counselors come in to assist the learners with accurate information on career pathways and subject requirements. The teachers collect current and historical student academic achievement data from formative assessments to advise the learners on their future career direction (Njeri, 2007). However, this is an area where Kenyan teachers have not done very well in advising students about. Ndungu (2008) points out that most students are not aware of the academic requirements and grades when making their career choices in schools. Yet, the knowledge of academic abilities for every programme are pointers to the mental preparedness of an individual learner for the career programme he/she intends to pursue (Gibson \& Mitchell, 2003). Career advice needs to students need to be streamlined and strengthened. As Mudula, Ayiro, and Kipsoi (2017) pointed out, the contribution of both the overall academic performance and subject-based achievement in making post-secondary career training decisions need to be emphasized in schools.

\subsubsection{Parent-Teacher Conferences}

The use of assessment data is to inform parents of the child's academic progress (Wanjiru, 2011). In Kenya, teachers use assessment data to initiate dialogue with parents about the learners' academic achievements (Waiswa, 2016). Most academic conferences take place after the first continuous assessment tests in schools. In academic conferences in schools, teachers use the learners' academic scores to engage the parents in a friendly one-on-one conversation about the strategies the school administration, the teacher, and the parent all need to collectively or individually undertake to turnaround the poor student academic performance (Mwirichia, 2012).

A parent-teacher conference is an opportunity for the teachers and parents to share information on the academic progress of the learner based on the test scores, assessments, portfolios, etc. The conferences are also opportunities for the teachers to learn the students' strengths, weaknesses, distractions from learning, learning styles, needs, and behaviours from the parents. To have a better understanding of the learners, both parents and teachers discuss intervention strategies that promote students' learning growth (Hill \& Tyson, 2009). Mwirichia (2012) observes that active parental involvement in school activities such as honouring academic invitations from teachers improve learners' grades in examinations and build the educational character of the Kenyan child.

\subsection{Challenges of Data Use in Curriculum and Instruction in Kenya}

The following challenges impede effective data use in curriculum and instruction in schools.

\subsubsection{Lack of Data Analysis Skills}

Most principals and teachers in Kenya lack essential data analysis skills, such as using spreadsheet management to analyze and organize data (Walekhwa, Achoka, \& Ndiku, 2016; Singoro, 2012). For this reason, teachers record raw student marks (data) in their professional records without a critical analysis of class performance (Kwaka, 2003). Most teachers fail to dissect the continuous assessment data using both measures of central tendency such as means, mode, and median and measures of spread, such as standard deviation (Singoro, 
2012). The teachers' failure to analyze the assessment results using the statistical procedures means that teachers are not sufficiently proficient in data analysis skills for effective use of data in classroom based decision making (Kwaka, 2003).

\subsubsection{Lack of Time for Data Analysis}

Kenyan teachers have huge workloads that affect their instructional preparation, classroom delivery, and limit their time for data collaboration (Kimani, Kara, \& Njagi, 2013). The official average teacher workload in public secondary schools is 27 lessons per week (Republic of Kenya, 2014). The current average teacher workload in most schools stands at 35 (Ngaruiya, Odundo, \& Gunga, 2014). Although the workload varies from teacher to teacher and from school to school, majority of teachers in secondary schools are overworked. Besides, the heavy workload is expected to rise as the government implements the 100 percent transition of learners from primary to secondary schools in 2020. An overloaded and overworked teacher has less time to analyze data and collaborate with other colleagues in discussions about the use of data in school improvement.

\subsubsection{Inadequate Data Management Resources}

Information Communication and Technology (ICT) gadgets are essential resources in promoting technology and data use in schools. Computers enhance data collection, analysis, storage, and retrieval. There is, however, low penetration of ICT infrastructure in Kenyan public secondary schools to support data use. The percentage of schools with functional computer hardware varies between 26 to 50 percent (Walekhwa et al., 2016). The percentage of schools with spreadsheet software tailored explicitly for data analysis is much lower (Walekhwa et al., 2016). Muthoni (2014) notes that "limited access to computers among the Heads of Departments could affect the efficiency of data management as they are the primary source of school data" (p. 55). The schools with a stock of ICT hardware are also facing pilferage and theft of the gadgets. The government notes with concern that the high cost and theft of ICT hardware has exacerbated the magnitude of inadequacies across schools.

ICT is expensive, and most schools are still facing the challenge of inadequate ICT infrastructure for teaching and learning. In some cases, the hardware is inefficient because of the lack of adequate maintenance. Vandalism and theft of ICT and other accessories has also increased the magnitude of the problem (Republic of Kenya, 2015 p. 98)

\subsubsection{Organizational Culture}

At the national level, the existing management practices in the education sector are yet to support evidence-based decision making in schools (Republic of Kenya, 2019b). The culture of data use to make decisions is still fraught with several challenges, such as inadequate ICT resources, lack of data use skills, and inefficient data collection and monitoring process (Republic of Kenya, 2019b). These challenges apparent at the macro education level have cascaded down to schools creating a laxity on the collection and utilization of data. Ndiku, Oyoo, and Owano (2014) found that "both the principals and teachers lacked adequate set of student data for them to use to aid effective planning. The implication was that decisions made in schools were not based on data" (p. 585). In most schools, teachers indeed collect assessment data to fulfill school administration requirements and principals collect data for 
reporting to higher authorities rather than for use in classrooms to meaningfully change instruction (Kwaka, 2003).

\subsubsection{Poor Leadership on Data Use}

The low use of assessment data is exacerbated by principals who do not take the lead to champion data use in their schools. Such leaders may not lead institutions successfully to adopt data use. Reeves and Burt (2006) contend that leadership is crucial to data use, and principals without adequate knowledge in the collection, analysis, and interpretation of data have more difficulty leading their teachers through evidence-based decision making in their schools. School leaders with a strong commitment to data-driven decision making create enabling environments that sustain data use, while leaders who are averse to the idea hinder sufficient data use practices (Mason, 2002). Leaders who use data to support their management decisions build visions for effective teachers' data use in their schools (Lachat \& Smith, 2005). In Kenya, most school principals are not aware that data use in schools begins with principal leadership. Principals cannot effectively lead the rest of the teaching staff to use what they do not comprehend fully (Ndiku et al., 2014).

\section{Opportunities}

i) There is unprecedented political goodwill from the government to improve Information Computer Technology and by extension, the use of data in schools. First, the Centre for Mathematics, Science and Technology Education in Africa (CEMASTEA), a government agency, has been offering continuous professional development training to Mathematics and Science secondary school teachers on the adoption of computer technology in the teaching and learning process. CEMASTEA develops innovative teaching methods and annually conducts workshops and seminars for teachers on newer strategies of teaching such as the use of ICT in teaching. For instance, in 2018, CEMASTEA trained a total of 8,013 teachers of Mathematics and Science on the use of assessments in the teaching and learning (www.cemastea.ac.ke). Secondly, in the new teacher appraisal policy document, teachers are supposed to set their own targets when adopting Computer Technology in instruction and provide evidence of use of technology in planning and delivery of content in classroom (Republic of Kenya, 2017).

ii) The government intends to invest in the professional development of teachers for intensive ICT use (Republic of Kenya, 2019). In this regard, teachers should take advantage of the abundant training opportunities offered by the Center for Mathematics Science and Technology in Education in Africa for teachers in data use management. Teachers can take advantage of such opportunities to improve their ICT skills.

iii) The government is employing teachers on a contract basis to reduce shortage and improve pupil-teacher ratios. This initiative to hire more teachers will reduce teacher workload, thus creating more time for teachers to analyze, interpret, collaborate, and engage with other colleagues in data use in schools.

\section{Conclusion}

Although the literature on teachers' use of assessment data is developing, this article has attempted to highlight teacher's use of assessment data in Kenyan schools. The demands of 
high stakes accountability where the government uses assessment data, as one of the proxy measures of teacher effectiveness, to make, among others, teacher promotion decisions will inevitably force instructors to rethink their engagement with data. Although teachers use assessment data for identifying weak learners, monitoring academic progress, assessing content mastery, initiating parent-teacher conversation and for grading the learners, data needs to be used more robustly to make classroom based decisions that improves student academic achievement. School principals too need to support teachers in their quest for data based instruction by removing the attendant data use barriers in schools. In addition, the school leaders should also take a lead role in making decisions that are supported by data. In furtherance of use of data, principals also need to accord teachers the opportunities to improve their data use skills and develop adequate ICT infrastructure in schools.

\section{References}

Anderson, S., Leithwood, K., \& Strauss, T. (2010). Leading Data Use in Schools: Organizational Conditions and Practices at the School and District Levels. Leadership and Policy in Schools, 9(3), 292-327. https://doi.org/10.1080/15700761003731492

Bernhardt, V. L. (2003). Measuring school processes. Education for the Future, 1(11), 1-11.

Black, P., \& Wiliam, D. (1998). Assessment and classroom learning. Assessment in Education, 5(1), 7-74. https://doi.org/10.1080/0969595980050102

Boit, M., Njoki, A., \& Changach, J. K. (2012). The Influence of Examinations on the Stated Curriculum Goals. America international Journal of Contemporary Research, 2(2), 179-183.

Breiter, A., \& Light, D. (2006). Data for school improvement: Factors for designing effective information systems to support decision making in schools. Educational Technology and Society, 9(3), 206-217.

Buhere, K. (2010). Teaching Abusing Remedial Teaching (p. 16). Nairobi. The Standard.

Carlson, D., Borman, G., \& Robinson, M. (2011). A multistate District-Level Cluster Randomized Trial of the Impact of Data-Driven Reform on Reading and Mathematics Achievement. Education and Evaluation and Policy Analysis, 33(3), 378-398. https://doi.org/10.3102/0162373711412765

Cawelti, G., \& Protheroe, N. (2001). High Student Achievement: How Six School Districts Changed into High-Performance Systems. Arlington, VA: Educational Research Service.

Education Commission on the States. (2002). Data-driven decision making (No Child Left Behind Issue Brief, Report: GP-02-10). Denver, CO: Author.

Gibson, R. L., \& Mitchell, M. H. (2003). Introduction to Counseling and Guidance. New Jersey. Pearson Education, Inc.

Henry, E. K., Nyaga, V. K., \& Oundo, M. B. (2014). Effects of Examination Oriented Teaching on Academic Aspiration among Secondary School Students in Imenti South District, Kenya. International Journal for Innovation Education \& Research, 2(5), 58-66.

Hill, N. E., \& Tyson, D. F. (2009). Parental Involvement in Middle School. A Meta-Analytic Assessment of Strategies That Promote Achievement. Development Psychology, 45(3), 740-763. https://doi.org/10.1037/a0015362 
Hoover, N. R., \& Abrams, L. M. (2013). Teachers' instructional use of summative student assessment data. Applied Measurement in Education, 26(3), 219-231. https://doi.org/10.1080/08957347.2013.793187

Italiano, F., \& Hine, G. (2014). Finding Ways to Effectively Use Year 12 Achievement Data to Inform Practice in Secondary Schools. Australian Journal of Teacher Education, 39(5). https://doi.org/10.14221/ajte.2014v39n5.8

Kagete, P. M. (2013). 186-Classroom Assessment-for-Learning in Secondary Schools in Kenya. A paper presented at the $39^{\text {th }}$ Annual Conference of International Association for Educational Assessment IAEA in Tel Aviv Israel, August 2013.

Khombe, M. (2014). A desk Study of the Education Policy Implications of Using Data from Multiple Sources: Examples of Primary School Teacher Supply and Demand in Malawi. All theses and Dissertations, 4366. https://scholarsarchive.byu.edu/etd/4366

Kimani, G. N., Kara, A. M., \& Njagi, L. W. (2013). Teacher factors influencing students' academic achievement in secondary schools in Nyandarua County, Kenya. International Journal of Education and Research, 1(3).

Kipkorir, E. K. (2015). Classroom Assessment Practices by Mathematics Teachers in Secondary Schools of Kenya. Unpublished Masters of Education Thesis. The University of Nairobi.

Kwaka, D. K. (2003). Influence of Teachers Assessment Practices in Enhancing Performance in Mathematics Among Secondary School Students in Mombasa District, Kenya. Unpublished Masters Thesis, Kenyatta University.

Lachat, M. A., \& Smith, S. (2005). Practices That Support Data Use in Urban High Schools. Journal of Education for Students Placed at Risk, 10(3), 333-49. https://doi.org/10.1207/s15327671espr1003_7

Lezotte, L. (2001). Revolutionary and evolutionary: The effective schools movement. Okemos, MI: Effective Schools Products, Ltd.

Mackatiani, C. I., Joseph, M. N., \& Komo, G. D. (2017). Quality Primary Education In Kenya: Implications of Teachers' characteristics. European Journal of Education Studies, 3(8), 635-650.

Management Study Guide. (2012). Desk Research-Methodologies and Techniques. Retrieved from http://www.managementstudyguide.com/desk-research.htm

Marsh, J. A., Pane, J. F., \& Hamilton, L. S. (2006). Making sense of data-driven decision making in education. Santa Monica, CA: RAND Corporation.

Marston, D., Pickart, M., Reschly, A., Heistad, D., Muyskens, P., \& Tindal, G. (2007). Early literacy measures for improving student reading achievement: Translating research into practice. Exceptionality, 15(2), 97-117. https://doi.org/10.1080/09362830701294177

Mason, S. (2002). Turning data into knowledge: Lessons from six Milwaukee public schools (Working Paper No. 2002-3). Madison: University of Wisconsin, Wisconsin Center for Education Research.

Militello, M., Bass, L., Jackson, K. T., \& Wang, Y. (2013). How data are used and misused in 
schools: Perceptions from teachers and principals. Education Sciences, 3(2), 98-120. https://doi.org/10.3390/educsci3020098

Mudulia, A. M., Ayiro, L. P., \& Kipsoi, E. (2017). Relationship between forms of career guidance, academic performance and subsequent career choice of high school girls: A case of Vihiga County, Kenya. Journal of Education and Practice, 8(15), 194-206. Retrieved from https://eric.ed.gov/?id=EJ1143834

Mwirichia V. M. (2012). Influence of Parental Involvement on Academic Performance of Preschool Children in Kangeta Division, Meru County. Kenya Masters' Thesis, U.O.N. Retrieved from http://www.uonlibrary.uonbi.ac.ke

Nasibi, W. (2003). Instructional Methods- Teaching Across the Curriculum. Strongwal Africa, Nairobi.

Ndiku, J. M., Oyoo, O. N., \& Owano, A. (2014). Student Data Management and Decision Making in Kenya. Internal Journal of Education and Research, 2(6), 577-590.

Ndungu, O. N. (2008). The Role of Career Guidance and Counselling in Career Awareness \& Planning Among Public Secondary School Students in Kenya. Unpublished Doctoral Thesis, Egerton University.

Ngaruiya, B., Odundo, P., \& Gunga, S. O. (2014). Instructional planning among teachers in public secondary schools: Factors that influence performance in business studies. Sociology Study, 4(5), 395-410.

Njeri, N. P. (2007). The Influence of Guidance and Counselling on Academic Programs of Selected Secondary Schools: A case of Bahati Division Nakuru District. Unpublished Masters of Education Thesis, Egerton University.

Oláh, L. N., Lawrence, N. R., \& Riggan, M. (2010). Learning to learn from benchmark assessment data: How teachers analyze results. Peabody Journal of Education, 85, 226-245. https://doi.org/10.1080/01619561003688688

Omoso E. O. (2012). Data-Based Decision Making in the School Environment: An Assessment of Data Use by Secondary School Teachers in Kisumu East District, Kenya. Unpublished Masters Thesis. University of Twente.

Perie, M., Marion, S., \& Gong, B. (2009). Moving toward a comprehensive assessments system: A framework for considering interim assessments. Educational Measurement: Issues and Practice, 2(8), 5-13. https://doi.org/10.1111/j.1745-3992.2009.00149.x

Reeves, P. L., \& Burt, W. L (2006). Challenges in data-based decision-making: Interview Studies. New York, NY: The Free Press.

Republic of Kenya. (2001). Report of the Taskforce on Student Discipline and Unrest in Secondary Schools. Nairobi, Jomo Kenyatta Foundation.

Republic of Kenya. (2008). Kenya National Examinations Report. Nairobi. Government Printers.

Republic of Kenya. (2011). Taskforce report on the re-alignment of the education sector to the constitution of Kenya 2010: Towards a globally competitive quality education for sustainable development. Nairobi. Government Printers. 
Republic of Kenya. (2015). National Education Sector Plan: Basic Education Program Rationale and Approach 2013-2018 Volume One. Nairobi. Government Printers.

Republic of Kenya. (2017). Performance Contract Between the Teachers Service Commission and Principals of Secondary Schools Document. TSC, Nairobi.

Republic of Kenya. (2019). Sessional Paper No 1 of 2019 on a Policy Framework for Reforming Education and Training for Sustainable Development in Kenya. Nairobi. Government Printer.

Rudner, L. M., \& Boston, C. (2003). Data warehousing: Beyond desegregations. Educational Leadership, 60(5), 62.

Schildkamp, K., \& Handelzalts, A. (2011). Data teams for school improvement. Paper presented at the American Educational Research Association Conference, New Orleans, USA.

Stachowiak, J. E. (2013). Student achievement data systems in high and low performing schools. Western Illinois University

Wabwoba, F., \& Mwakondo, F. M. (2011). Students Selection for University Course Admissions at the Joint Admissions Board (Kenya) Using Trained Neural Networks. Journal of Information Technology Education: Research, 10(1), 333-347. https://doi.org/10.28945/1529

Waiswa, E. F. (2016). Relationship between Parent Teacher Communication and Parental Involvement in Pre-Primary School Children's Reading in Mumias East sub-County. Unpublished Master of Education Thesis, Kenyatta University, Nairobi.

Walekhwa, D. W., Achoka, J. S. K., \& Ndiku, J. M. (2016). Establishment of EMIS Infrastructure in Public Secondary Schools in Rarieda Sub-County, Kenya. Journal of Advances in Social Sciences, 2(3), 7-15. https://doi.org/10.15520/jassh2337

Wanjiru, D. W. (2011). Assessment of Formative Evaluation in Teaching and Learning Secondary Mathematics: A Case of Thika West District, Kiambu County. Unpublished Masters of Education Thesis. Kenyatta University. Nairobi.

Wayman, J. C. (2005). Involving Teachers in Data-Driven Decision Making: Using Computer Data Systems to Support Teacher Inquiry and Reflection. Journal of Education for Students Placed at Risk (JESPAR), 10(3), 295-308. https://doi.org/10.1207/s15327671espr1003_5

Young, V. M., \& Kim, D. H. (2010). Using assessments for instructional improvement: a literature review. Education Policy Analysis Archives, 18(19). https://doi.org/10.14507/epaa.v18n19.2010

\section{Copyright Disclaimer}

Copyright for this article is retained by the author(s), with first publication rights granted to the journal.

This is an open-access article distributed under the terms and conditions of the Creative Commons Attribution license (http://creativecommons.org/licenses/by/3.0/). 